\title{
FAKTOR-FAKTOR YANG MEMPENGARUHI PRODUKSI JAGUNG DI DESA KIRITANA KECAMATAN KAMBERA KABUPATEN SUMBA TIMUR
}

\author{
FACTORS AFFECTING CORN PRODUCTION IN KIRITANA VILLAGE, KAMBERA \\ DISTRICT, SUMBA TIMUR DISTRICT
}

\author{
Anggreni Madik Linda \\ Program Studi Agribisnis Universitas Kristen Wira Wacana Sumba \\ Jl. R. Suprapto, No.35 Waingapu, Kab. Sumba Timur -NTT \\ E-mail: rennylinda25@gmail.com \\ (Diterima 09-05-2020; Disetujui 17-06-2020)
}

\begin{abstract}
ABSTRAK
Penelitian ini bertujuan untuk mengetahui faktor-faktor yang mempengaruhi produksi jagung di Desa Kiritana, Kecamatan Kambera Kabupaten Sumba Timur. Penelitian ini dilakukan pada bulan Januari 2020. Metode pengambilan responden menggunakan simple random sampling sebanyak 30 petani responden. Penelitian ini menggunakan metode kuantitatif deskriptif. Hasil penelitian ini menunjukkan bahwa variable luas lahan (X1), benih (X2), jumlah tenaga kerja (X3) dan penggunaan herbisida (X4) berpengaruh signifikan secara serempak terhadap produksi jagung. Secara parsial, variabel luas lahan (X1) dan benih (X2) berpengaruh signifikan terhadap produksi jagung, sedangkan jumlah tenaga kerja (X3) dan penggunaan herbisida (X4) tidak berpengaruh secara signifikan.
\end{abstract}

Kata kunci: Faktor produksi, Jagung, Produksi

\begin{abstract}
This study aims to determine the factors that influence corn production in Kiritana Village, Kambera District, East Sumba Regency. This research was conducted in January 2020. The method of taking respondents using simple random sampling of 30 farmer respondents. This research uses descriptive quantitative method. The results of this study indicate that the variable land area $\left(X_{1}\right)$, seeds $\left(X_{2}\right)$, the number of labor $\left(X_{3}\right)$ and the use of herbicides $\left(X_{4}\right)$ simultaneously have a significant effect on corn production. Partially, the variable land area $\left(X_{1}\right)$ and seed $\left(X_{2}\right)$ have a significant effect on corn production, while the number of labor $\left(X_{3}\right)$ and herbicide use $\left(X_{4}\right)$ have no significant effect.
\end{abstract}

Keywords: Production factors, Corn, Production

\section{PENDAHULUAN}

Jagung merupakan salah satu tanaman pangan yang banyak dikonsumsi oleh masyarakat Indonesia serta biasa digunakan sebagai bahan makanan pokok pengganti beras. Jagung adalah komoditi tanaman pangan yang potensial untuk dikembangkan karena merupakan sumber utama karbohidrat dan protein. Jagung menjadi salah satu komoditas pertanian yang sangat dan saling terkait dengan industri besar (Bantaika, 2017).

Kiritana merupakan salah satu desa yang terletak di Kecamatan Kambera, Kabupaten Sumba Timur, Provinsi Nusa Tenggara Timur. Desa Kiritana 
merupakan desa yang hampir semua masyarakat bekerja di bidang pertanian. Produk unggulan dari Desa Kiritana adalah produk hortikultura (terong, sayurmayur, cabe, dan sebagainya), dan tanaman pangan seperti jagung. Berdasarkan data BPS NTT (2016), Kabupaten Sumba Timur merupakan salah satu penghasil jagung di Provinsi NTT dengan produksi 50.514 ton dan berada di urutan ke 5 sebagai penghasil jagung di Provinsi NTT.

Petani jagung di Desa Kiritana melakukan penanaman jagung sebanyak 2 (dua) kali dalam setahun, dikarenakan Desa Kiritana berada di daerah aliran sungai (DAS) yaitu musim hujan dan musim kemarau. Namun permahasalahan yang dihadapi petani jagung di Desa Kiritana adalah pola produksi yang kurang baik dan tidak berdasarkan anjuran sehingga hasil yang didapatkan petani belum maksimal. Selain itu, juga keterbatasan modal merupakan masalah utama yang terjadi di kalangan petani. Oleh karena itu, tujuan penelitian ini adalah untuk mengetahui faktor-faktor yang mempengaruhi produksi jagung di Desa Kiritana.

\section{METODE PENELITIAN}

Metode penelitian yang digunakan dalam penelitian ini adalah metode penelitian kuantitatif deskriptif yaitu dengan cara mencari informasi tentang gejala yang ada, didefinisikan dengan jelas tujuan yang akan dicapai, merencanakan cara pendekatannya, mengumpulkan data sebagai bahan untuk membuat laporan, sedangkan penentuan lokasi diambil secara sengaja (purvosive sampling) di salah satu desa yang merupakan sentra produksi jagung yaitu Desa Kiritana, Kecamatan Kambera, Kabupaten Sumba Timur.

Populasi penelitian ini adalah petani jagung yang aktif di Desa Kiritana sebanyak 130 orang, dan diambil sampel sebanyak 30 orang. Pengambilan sampel sebanyak 30 orang mengacu pada Dermawan (2013) yang menyatakan bahwa ukuran sampel sebaiknya adalah 30 sampai dengan 500 sampel. Metode yang digunakan untuk pengambilan petani sampel menggunakan metode simple random sampling (acak sederhana) yaitu teknik pengambilan sampel diundi dengan pengambilan, pemilihan sampel dari unit-unit sampel sedemikian rupa sehingga setiap unit sampel mendapat peluang yang sama. 
Dalam penelitian ini menggunakan model analisis regresi berganda dengan model kuadran terkecil (Ordinary Least Square, OLS). Analisis ini dugunakan untuk mengetahui faktor-faktor yang mempengaruhi pendapatan usahatani yang secara matematis dapat dirumuskan dengan menggunakan pendekatan statistika sebagai berikut:

$Y=\beta_{0}+\beta_{1} X_{1}+\beta_{2} X_{2}+\beta_{3} X_{3}+\beta_{4} X_{4}+e$

Persamaan di atas kemudian dilinearkan dengan menggunakan logaritma natural (ln) maka membentuk persamaan sebagai berikut:

$\operatorname{Ln} Y=\beta_{0}+\beta_{1} \ln X_{1}+\beta_{2} \ln X_{2}+\beta_{3} \ln X_{3}+$ $\beta_{4} \ln \mathrm{X}_{4}+\mathrm{e}$

Keterangan:

$\mathrm{X}_{1} \quad=$ Luas lahan $(\mathrm{Ha})$

$\mathrm{X}_{2} \quad=$ Benih $(\mathrm{Kg})$

$\mathrm{X}_{3} \quad=$ Jumlah tenaga kerja (Orang)

$\mathrm{X}_{4} \quad=$ Penggunaan Herbisida $(\mathrm{L})$

$\mathrm{Y} \quad=$ Produksi Jagung $(\mathrm{Kg})$

$\mathrm{B}_{0} \quad=$ Konstanta

$\beta_{1}-\beta_{4}=$ Koefisien Regresi

$\mathrm{e} \quad=$ eror

\section{HASIL DAN PEMBAHASAN}

\section{Keadaan Umum Daerah Penelitian}

Luas wilayah Desa Kiritana adalah 1.540 ha atau $15,4 \mathrm{~km}^{2}$ dengan jumlah penduduk paling sedikit di Kecamatan Kambera yaitu 894 jiwa yang terdiri atas laki-laki 461 jiwa dan perempuan 433 jiwa. Mata pencaharian utama masyarakat di Desa Kiritana adalah sebagai petani, selain itu sebagai peternak, nelayan, dan pedagang (BPS, 2019).

\section{Karakteristik Petani}

Dari hasil olahan data penelitian, diketahui bahwa umur petani responden berkisar antara 20-60 tahun, dimana sebagian besar petani responden berpendidikan SD yaitu sebesar 20 responden. Petani responden memiliki pengalaman kerja dalam usahatani jagung mulai dari 4-20 tahun. Status kepemilikan lahan semua petani responden adalah milik sendiri dengan rata-rata kepemilikikan 1.15 ha.

\section{Teknik Budidaya}

Penanaman jagung di Desa Kiritana dilakukan dalam 2 musim tanam dikarenakan Desa Kiritana berada di daerah aliran sungai (DAS) yaitu musim hujan dan musim kemarau. Jenis jagung yang ditanam adalah varietas lamuru. Tenaga kerja yang digunakan dalam proses penanaman adalah anggota keluarga dari petani tersebut dan terkadang dilakukan secara gotong royong dengan anggota kelompok tani. Berikut merupakan tahapan yang dilakukan dalam penanaman jagung di Desa Kiritana: 
1. Penyiapan lahan, merupakan kegiatan yang dilakukan sebelum penanaman agar pelaksanaan tanam menanam lebih mudah dan memberikan hasil yang baik. Pengolahan tanah dilakukan menggunakan traktor agar dapat menggemburkan tanah karena jagung memerlukan aerase dan drainase yang baik.

2. Penanaman, merupakan kegiatan yang dilakukan setelah penyiapan lahan. Untuk penanaman biasanya dengan jarak antar lubang $75 \mathrm{~cm} \mathrm{x} 40 \mathrm{~cm} \mathrm{(2}$ biji per lubang).

3. Penyiangan, dilakukan dengan menyemprot herbisida namun masih dalam jumlah yang sedikit, dikarenakan petani jagung di Desa Kiritana lebih sering membersihkan lahan secara manual dan secara bergotong royong. Dalam proses ini, juga tidak dilakukan pemupukan karena petani di Desa Kiritana beranggapan bahwa tanah di desa tersebut tergolong subur karena setiap tahunnya selalu terjadi banjir yang menyebabkan meningkatnya kesuburan tanah.

4. Pemanenan, dilakukan secara manual menggunakan tangan dan dilakukan secara gotong royong oleh keluarga petani atau bersama anggota kelompok tani. Umur panen jagung berkisar antara 90-100 hari setelah penanaman.

5. Pasca panen, dilakukan setelah proses pemanenan. Jagung yang telah dipanen, kemudian diangkut dan dilakukan perontokan dengan menggunakan mesin, kemudian dijemur sampai kering, dan setelah itu dijual ke pasar atau pengepul.

\section{Faktor-faktor yang Mempengaruhi Produksi Jagung}

Analisis regresi berganda dalam penelitian ini digunakan untuk menentukan besarnya pengaruh variabel bebas $(\mathrm{X})$ terhadap variabel terikat $(\mathrm{Y})$. Variabel bebas dalam penelitian ini adalah luas lahan $\left(\mathrm{X}_{1}\right)$, benih $\left(\mathrm{X}_{2}\right)$, jumlah tenaga kerja $\left(\mathrm{X}_{3}\right)$, dan penggunaan herbisida $\left(\mathrm{X}_{4}\right)$; sedangkan variabel terikat adalah produksi jagung (Y). Sebelum dilakukan analisis regresi berganda, terlebih dahulu dilakukan uji asumsi klasik yang terdiri atas uji normalitas, uji autokorelasi, uji multikolinearitas dan uji heteroskedastisitas. Dari hasil analisis tersebut diperoleh bahwa:

1. Uji Normlitas, digunakan untuk menguji apakah data yang bersangkutan berdistribusi normal atau tidak. Dari hasil analisis nilai 
dari Asymp. Sig (2-tailed) adalah

0,200 dimana nilai tersebut $>0,05$

yang berarti bahwa data tersebut berdistribusi normal.

2. Uji Autokorelasi, jika nilai Durbin Watson (DW) lebih besar dari batas atas (du) dan kurang dari jumlah variabel independen, maka dapat disimpulkan bahwa tidak ada autokorelasi. Dari hasil analisis diperoleh nilai DW adalah 2,240 dan berdasarkan tabel DW ( $\alpha=5 \%)$ nilai du adalah 1,738. Karena nilai DW > du maka tidak terjadi autokorelasi.

3. Uji Multikolinearitas, uji ini bertujuan untuk menguji apakah dalam model regresi ditemukan adanya korelasi antara variabel independen. Berdasarkan aturan variance inflation factor (VIF) dan tolerance, maka apabila VIF melebihi angka 10 atau tolerance kurang dari 0,10 maka dinyatakan terjadi gejala multikolinieritas. Sebaliknya apabila nilai VIF kurang dari 10 atau tolerance lebih dari 0,10 maka dinyatakan tidak terjadi gejala multikolinieritas. Dari hasil analisis diperoleh bahwa nilai VIF dari masing-masing variabel berkisar 1,329-8,900 dan nilai tolerance berkisar 0,112-0,752 dan dapat

$\begin{array}{llr}\text { disimpulkan } & \text { bahwa } & \text { variabel } \\ \text { independen } & \text { terbebas } & \text { dari } \\ \text { multikolinearitas. } & & \end{array}$

4. Uji Heteroskedastisitas, untuk mendeteksi ada atau tidaknya heteroskedastisitas yaitu dengan melihat Grafik Plot antara nilai prediksi variabel terikat (dependen) yaitu ZPRED dengan residualnya SRESID. Deteksi ada atau tidaknya heteroskedastisitas dapat dilakukan dengan melihat ada tidaknya pola tertentu pada Grafik Scatterplot antara SRESID dan ZPRED dimana sumbu $\mathrm{Y}$ adalah $\mathrm{Y}$ yang telah diprediksi dan sumbu X adalah residual (Y prediksi - Y sesungguhnya) yang telah distudentitized. Dari hasil analisis, tidak ada pola yang jelas, seperti titiktitik menyebar di atas dan di bawah angka 0 pada sumbu $Y$, maka dapat disimpulkan tidak terjadi heteroskedastisitas.

Berdasarkan hasil pengujian regresi pada Tabel 1 dapat diketahui model persamaan untuk pendugaan fungsi produksi Cobb-Douglass adalah sebagai berikut:

$$
\begin{aligned}
\text { Ln } \mathrm{Y}= & 6,462+0,546 \mathrm{X}_{1}+0,540 \mathrm{X}_{2}+ \\
& 0,010 \mathrm{X}_{3}+0,008 \mathrm{X}_{4}+\mathrm{e}
\end{aligned}
$$

Dari Tabel 1 diperoleh hasil $\mathrm{R}^{2}$ sebesar 0,961 yang artinya $96,1 \%$ variasi 
variabel produksi jagung dapat dijelaskan oleh variabel luas lahan, benih, jumlah tenaga kerja dan penggunaan herbisida. Sedangkan sisanya sebesar 3,9\% diduga dipengaruhi oleh variabel lain di luar penelitian ini. Persamaan regresi faktorfaktor yang mempengaruhi produksi jagung adalah sebagai berikut:

\section{Uji F (Uji Serempak)}

Dari hasil analisis regresi linier berganda menunjukan bahwa nilai $\mathrm{F}$ hitung sebesar 156,008 dan tingkat signifikansi sebesar 0,000. Dengan demikian sig. F $0,000<0,05$ maka variabel independen (luas lahan, benih, jumlah tenaga kerja dan penggunaan herbisida) secara bersama-sama mempunyai pengaruh yang signifikan terhadap variabel dependen (produksi jagung).

\section{Uji t (Uji Parsial)}

Hasil uji pengaruh variabel bebas terhadap variabel terikat secara parsial dengan menggunakan uji $\mathrm{t}$ dapat dilihat pada Tabel 1. Untuk menguji apakah variabel bebas secara parsial berpengaruh atau tidak terhadap variabel terikat, maka dilakukan uji $\mathrm{t}$, nilai dari $\mathrm{t}$ hitung $>\mathrm{t}_{\text {tabel }}$ maka variabel bebas tersebut berpengaruh secara signifikan terhadap variabel terikat. Interpretasi setiap variabel bebas pada model dapat dijelaskan sebagai berikut:

\section{a. Luas Lahan $\left(\mathrm{X}_{1}\right)$}

Luas lahan memiliki hubungan yang positif terhadap produksi jagung dengan koefisien sebesar 0,546. Hal ini berarti bahwa kenaikan luas lahan sebesar 1\%, maka akan meningkatkan produksi jagung sebesar 0,546\%. Sebaliknya jika penggunaan luas lahan turun sebesar $1 \%$, maka hasil produksi akan turun sebesar $0,546 \%$. Secara parsial variabel luas lahan memiliki pengaruh terhadap produksi jagung dengan taraf kepercayaan 95\%. Di mana $\mathrm{t}$ hitung $>\mathrm{t}$ tabel $(4,513>1,708)$ dan tingkat signifikan $0,000<0,05$.

Luas lahan yang dimiliki setiap petani yang bertani jagung cenderung berbeda-beda, dari data yang didapat bahwa luas lahan yang paling sedikit seluas 0,53 ha dan luas lahan sebesar 2,20 ha. Sesuai hasil penelitian yang telah dilakukan, luas lahan mempengaruhi hasil produksi dikarenakan luas lahan semakin besar maka jumlah populasi tanaman jagung semakin banyak. Hal demikian memungkinkan akan menambah jumlah produksi. Sebaliknya, apabila luas lahan sedikit maka jumlah tanaman jagung pun semakin sedikit. Hal ini sejalan dengan penelitian 
Simanungkalit, et al (2017) yang menyatakan bahwa luas lahan merupakan salah satu faktor produksi yang mempengaruhi peningkatan produksi jagung.

\section{b. Benih $\left(\mathbf{X}_{2}\right)$}

Benih memiliki hubungan positif terhadap produksi jagung dengan koefisien sebesar 0,540. Hal ini dapat berarti apabila penggunaan jumlah benih naik sebesar $1 \%$, maka hasil produksi akan naik sebesar $0,540 \%$. Sebaliknya jika penggunaan jumlah benih turun sebesar 1\%, maka hasil produksi akan turun sebesar $0,540 \%$. Secara parsial variabel benih memiliki pengaruh terhadap produksi jagung dengan taraf kepercayaan 95\% dimana $t$ hitung $>t$ tabel $(3,985>1,708)$ dan tingkat signifikan $0,001<0,05$. Sesuai hasil penelitian yang dilakukan, benih mempengaruhi hasil produksi jagung karena semakin banyak benih yang digunakan maka semakin meningkat produksi jagung. Hal ini sesuai dengan penelitian yang dilakukan Tomy (2013), yaitu penggunaan benih berpengaruh nyata terhadap peningkatan produksi jagung. Jika penggunaan benih dinaikkan makan hasil prduksi jagung akan meningkat.

\section{c. Jumlah Tenaga Kerja $\left(\mathbf{X}_{3}\right)$}

Tenaga kerja memiliki hubungan yang positif terhadap produksi jagung dengan koefisien sebesar 0,010. Hal ini berarti bahwa penambahan tenaga kerja $1 \%$, maka akan menaikkan produksi jagung sebesar $0,010 \%$. Secara parsial variabel tenaga kerja tidak memiliki pengaruh terhadap produksi jagung dengan taraf kepercayaan 95\% dimana $\mathrm{t}$ hitung $<\mathrm{t}$ tabel $(0,107<1,708)$ dan tingkat signifikan $0,915>0,05$. Sesuai hasil penelitian yang dilakukan bahwa peningkatan jumlah tenga kerja yang digunakan dalam satu musim tanam produksi jagung tidak secara langsung meningkatkan produksi jagung, karena jika jumlah tenaga kerja yang digunakan oleh petani jagung tetap sama dalam setiap musim penanaman jagung sedangkan dalam setiap musimnya produksi jagung selalu berbeda. Sebaliknya, apabila jumlah tenaga kerja yang digunakan dalam musim tanam berbeda, tidak akan mempengaruhi secara langsung terhadap produksi jagung. Hasil penelitian ini sejalan dengan penelitian Isnuriyadi (2019) yang menyatakan bahwa jumlah tenaga kerja tidak berpengauh signifikan terhadap peningkatan produksi jagung. 


\section{d. Penggunaan Herbisida $\left(\mathbf{X}_{4}\right)$}

Penggunaan herbisida memiliki hubungan yang positif terhadap produksi jagung dengan koefisien sebesar 0,008. Hal ini berarti bahwa penambahan penggunaan herbisida 1\%, maka akan menaikkan produksi jagung sebesar 0,008\%. Secara parsial variabel penggunaan herbisida tidak memiliki pengaruh terhadap produksi jagung dengan taraf kepercayaan 95\% dimana $t$ hitung $<\mathrm{t}$ tabel $(0,163<1,708)$ dan tingkat signifikan $0,872>0,05$. Sesuai hasil penelitian yang dilakukan bahwa penggunaan herbisida oleh petani jagung di Desa Kiritana pada umumnya masih tergolong sedikit karena petani masih tetap melakukan pembersihan gulma secara manual dan gotong royong.

Tabel 1. Hasil Pengujian Produksi Jagung

\begin{tabular}{lccc}
\hline Variabel & $\begin{array}{l}\text { Koefisien } \\
\text { Regresi }\end{array}$ & $\mathbf{t}_{\text {hitung }}$ & Sig. \\
\hline Luas lahan & 6.462 & 13.680 & .000 \\
Benih & .546 & 4.513 & .000 \\
Jumlah tenaga & .540 & 3.985 & .001 \\
kerja & .010 & .107 & .915 \\
$\begin{array}{l}\text { Penggunaan } \\
\text { herbisida }\end{array}$ & & & \\
\hline $\mathrm{R}^{2}=0,961$ & & & \\
F hit $=156,008$ & & & \\
\hline
\end{tabular}

Sumber: Analisis Data Primer, 2020

\section{KESIMPULAN DAN SARAN}

Kesimpulan dari penelitian ini adalah variable luas lahan, benih, jumlah tenaga kerja dan penggunaan herbisida berpengaruh signifikan secara serempak terhadap produksi jagung. Secara parsial, variable luas lahan dan benih berpengaruh signifikan terhadap produksi jagung, sedangkan jumlah tenaga kerja dan penggunaan herbisida tidak berpengaruh secara signifikan.

Petani diharapkan menambah luas lahan dan memperhatikan penggunakan benih yang berkualitas agar produksi jagung yang dihasilkan semakin meningkat.

\section{DAFTAR PUSTAKA}

Bantaika, Y. (2017). Faktor-Faktor yang Mempengaruhi Produksi Usahatani Jagung di Desa Tesi Ayofanu, Kecamatan Kie, Kabupaten Timor Tengah Selatan. AGRIMOR, 2(01), 10-11.

https://doi.org/10.32938/ag.v2i01.1 27

BPS Prov. NTT,2016. Nusa Tenggara Timur Dalam Angka. Badan Pusat Statistik Nusa Tenggara Timur.

BPS Kab. Sumba Timur,2019. Kambera dalam Angka. Badan Pusat Statistik Kabupaten Sumba Timur.

Dermawan D. 2013. Metode Penelitian Kuantitatif. Bandung: PT Remaja Rosdakarya Offset.

Isnuriyadi, P. D. (2019). Analisis FaktorFaktor yang Mempengaruhi Produksi dan Pendapatan Petani Jagung (Studi Kasus: Desa Saentis, Kecamatan Percut Sei Tuan, Kabupaten Deli Serdang). Fakultas Pertanian. Universitas Medan Are. Medan.

Simanungkalit, C., Salmiah, S., \& Nasution, S. K. (2018). Analisis Faktor-Faktor Yang Mempengaruhi Produksi Jagung (Kasus: Desa 
Bertungen Julu Kecamatan Tigalingga Kabupaten Dairi). Journal on Social Economic of Agriculture and Agribusiness, 9(5).
Tomy, J. (2013). Faktor-faktor yang mempengaruhi produksi usahatani jagung Di Kecamatan Sindue Kabupaten Donggala. Agroland: Jurnal Ilmu-ilmu Pertanian, 20(1), 61-66. 